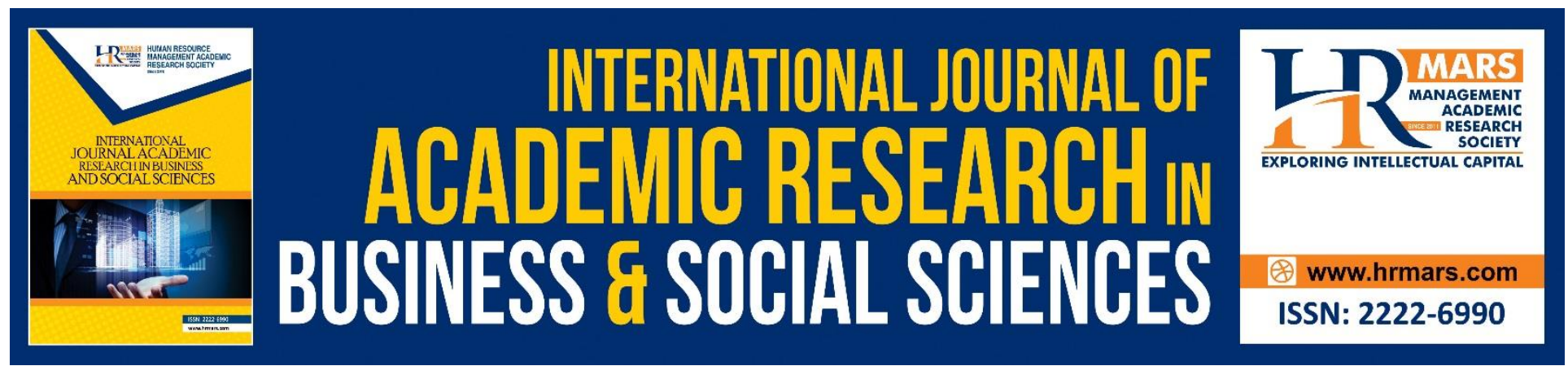

\title{
Covid-19 And Movement Control Order: Stress and Coping Strategies of Students Observing Self-Quarantine
}

Adam Andani Mohammed, Md. Sayed Uddin, Abdallah Mpawenimana Saidi

To Link this Article: http://dx.doi.org/10.6007/IJARBSS/v10-i5/7249

DOI:10.6007/IJARBSS/v10-i5/7249

Received: 25 March 2020, Revised: 28 April 2020, Accepted: 04 May 2020

Published Online: 27 May 2020

In-Text Citation: (Mohammed et al., 2020)

To Cite this Article: Mohammed, A. A., Uddin, M. S., \& Saidi, A. M. (2020). Covid-19 And Movement Control Order: Stress and Coping Strategies of Students Observing Self-Quarantine. International Journal of Academic Research in Business and Social Sciences, 10(5), 788-802.

Copyright: (C) 2020 The Author(s)

Published by Human Resource Management Academic Research Society (www.hrmars.com)

This article is published under the Creative Commons Attribution (CC BY 4.0) license. Anyone may reproduce, distribute, translate and create derivative works of this article (for both commercial and non-commercial purposes), subject to full attribution to the original publication and authors. The full terms of this license may be seen

at: http://creativecommons.org/licences/by/4.0/legalcode

Vol. 10, No. 5, 2020, Pg. $788-802$

http://hrmars.com/index.php/pages/detail/IJARBSS

JOURNAL HOMEPAGE

Full Terms \& Conditions of access and use can be found at http://hrmars.com/index.php/pages/detail/publication-ethics 


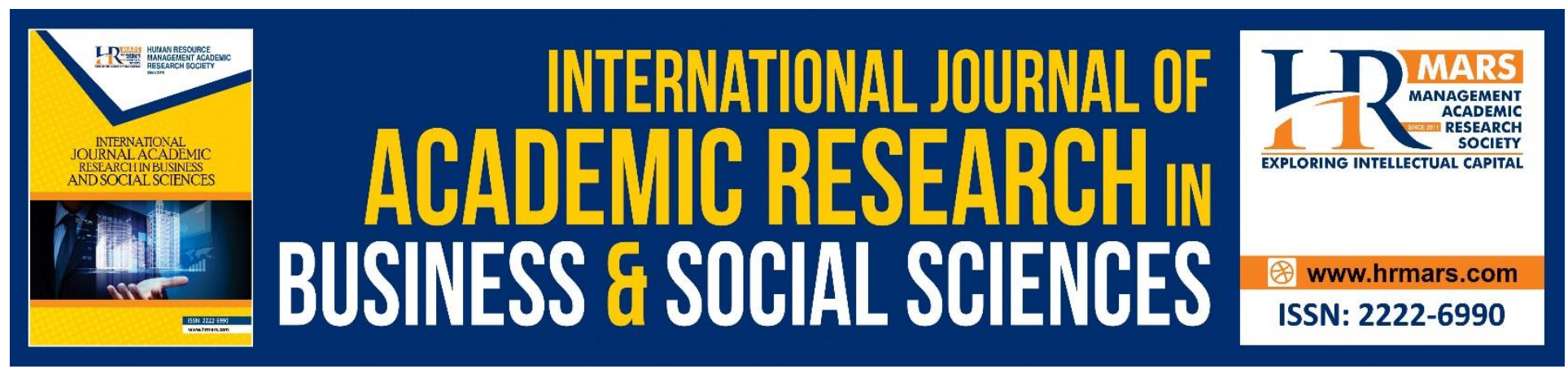

\title{
Covid-19 And Movement Control Order: Stress and Coping Strategies of Students Observing Self- Quarantine
}

\author{
Adam Andani Mohammed \\ Social Work Studies, Faculty of Social Science and Humanities, Universiti Malaysia Sarawak, \\ Kota Samarahan Sarawak, Malaysia. \\ Email: maandani@unimas.my \\ Md. Sayed Uddin \\ Sociology and Social Anthropology, Faculty of Humanities, Arts \& Heritage, Universiti Malaysia \\ Sabah, Jalan UMS, 88400, Kota Kinabalu, Sabah, Malaysia \\ Email: sayed@ums.edu.my
}

\begin{abstract}
Abdallah Mpawenimana Saidi
Universiti Malaysia Sarawak, Department of International Studies, Faculty of Social Science and Humanities

Email: mpawenimanaas@gmail.com
\end{abstract}

\begin{abstract}
Coronavirus Disease 2019 (COVID-19) led students feel anxious with a constant internal dialogue of 'Am I safe?' that may take a serious toll on their psyche. The self-quarantine and physical distancing, economic hardship and fears of contracting the disease are likely sources of stress. Quite apart, students may also experience both physical sufferings and mental stress due to the news of increasing number of infected cases and reported deaths across the globe. A range of expert guidelines have been developed by governments and health authorities to curtail the spread of the virus. This study models a position paper which persuades the reader to realize that the opinions expressed are valid and could be defended. In gathering supporting evidence, an online qualitative survey was conducted to examine the stress of students observing selfquarantine and physical distancing in and around Desa IImu and Unigardern in Kota Saramarahan as well as in apartments at Jalan Kingfisher Sabah. These students were invited as respondents in this online investigation using interview protocol to take their responses. This study is among the first to examine the stress and coping strategies of students observing self-quarantine and physical distancing. The paper may provide useful information about how students cope in
\end{abstract}


INTERNATIONAL JOURNAL OF ACADEMIC RESEARCH IN BUSINESS AND SOCIAL SCIENCES

Vol. 10, No. 5, May, 2020, E-ISSN: 2222-6990 @ 2020 HRMARS

stressful situations and also identify effective ways to manage people during distress times in future.

Keywords: Physical Distancing; Self-Quarantine, Coronavirus, Pandemic, Sanitisers, Compassion.

\section{Introduction}

"... Pandemics have a way of cutting through a lot of noise and spin to remind us of what is real and what is important. This crisis has reminded us that government matters. It's reminded us that good government matters that the facts and science matter that the rule of law matters that having leaders who are informed and honest and seek to bring people together rather than drive them apart. ... kind of leaders matter ..." (HE Barak Obama, Former President of the United States of America)

The world seems to have forgotten about other life threatening infectious diseases, climate change, terrorism, wars and famines due to the threats of COVID-19. It is very clear that the disease is neither a respecter of anybody nor discriminates in its attack. Self-quarantine, force isolation, physical distancing, frequent washing of hands and usage of sanitizers become the order of the day irrespective of sex, gender, race, ethnicity, poverty level, wealth, a celebrity, an older adult, a new-born child or socioeconomic and political class. The world turned to believed that it is military might or sophisticated weapons that can save humanity but to the surprise of all it is rather soap which does the magic this time. The Coronavirus Disease 2019 (COVID-19) described as invisible enemy leaves devastating mark on the psyche of people, including students across the world. The World Health Organization (WHO) declared the disease as a public health emergency of international concern on 30th January 2020 and on 11th March declared as pandemic (Emanuel et al., 2020; Felix et al., 2020). With this declaration, the fear of getting infected gripe everybody considering its clandestine spreading properties. As a result, governments, health authorities and law enforcement agencies of various countries ordered the general public to avoid both necessary and unnecessary forms of gathering but rather observe self-quarantine, physical distancing among others. Several studies show that governments around the world had started to issue unprecedented public policies such as social distancing, isolation, and self-quarantine (Anderson, et al., 2020; Pakpour, \& Griffiths, 2020). For instance, movement control order in different forms had been implemented with the threat of fines and/or imprisonment for breaching those controls in some countries. Since mid-March 2020, stringent measures for controlling the novel coronavirus have been gradually enforced and strengthened in Malaysia. To enforce the controls order, it was advised further that people stay and work from home and students at various levels of education system closed down or self-quarantine those on campuses. Besides, businesses, industries, the hospitality industry (hotels, airlines) and others were all down to their knees at the mercy of COVID-19.

The world never anticipated the COVID-19 pandemic would lead to the worst days for healthcare providers and patients. The information of how the pandemic rapidly spread across the globe and the scrambling of scientists and health care providers to figure out how to effectively treat COVID-19 is a source of worry for all. According to Shanthakumar, Seetharam, \& Ramesh, (2020), with no cure in sight and with the chances of COVID-19 reemerging again even after the world manages to contain this first outbreak is critical to understand and analyze its disruptions. Some stressors unique to the disease include fear of exposure to infection, subsequent risk to infect family members and loved ones, and concerns about educational progression. Studies indicate 
that a significant number of people will experience stress and fear of contagion, impact of prolonged quarantine and the death of relatives (Wang et al., 2020; Zhou, 2020; Brooks et al., 2020; Xiao, 2020; Felix et al., 2020; Polizzi, Lynn, \& Perry, 2020; Darwish, Ahmed, \& Pahi, 2020). As part of the stressors, information about hospital workers on the front lines of the COVID-19 getting infected due to inadequate Personal Protective Equipment PPEs causes discomfort among the public. In the absence of PPEs, healthcare personnel become powerless when patients express real fear of the virus but cannot get the usual intimate attention due to the numbers on admission. As such, information of the unprecedented loss of lives and that the COVID-19 pandemic is far from over is excruciating making everyone vulnerable. According to Xiao, Zhang, Kong, Li, and Yang, (2020), infectious disease epidemics not only affect the physical health of patients but also affect the psychological health and wellbeing of the non-infected population. This also leads to psychological disturbance as the fear of being infected lingers around those who are not infected. Invariably, people who are observing self-quarantine may show signs of frustration due to the information about the number of infections and the inability of healthcare providers to show compassion to patients with COVID-19. The intimate interactions between patients and healthcare providers could no longer be observed due to the need to observe physical distancing. As such, it is a common knowledge that standing at the bedside and holding patients' hand to console and ease their anxiety might not also be possible in attending to COVID-19 patients for safety reasons.

The spread of the virus affect not only the economy but also the education system. The impacts of the pandemic spread to all educational institutions the world over as such various countries imposed lockdown, force isolation, physical distancing and quarantine to control the spread. Nicomedes and Avila (2020) with the rapid spread of global pandemic COVID-19, people around the world express panic in various behaviors. As such, policies and guidelines were put in place to reduce the interaction of people who may spread the virus. UNESCO reports indicate that more than 160 countries have implemented national closures of educational institutions and that about $1,524,648,768$ students were affected due to the covid-19 virus which represent $87,1 \%$ of the total students enrolled (UNESCO, 2020; Abidah, Hidaayatullaah, Simamora, Fehabutar, and Mutakinati, 2020). According to Abidah, et al. (2020), about 165 countries in Africa, Asia, Europe, the Middle East, North America, and South America have imposed restrictions on schools and universities. It is revealed that students who are potentially at risk from pre-primary to high school level is 577,305,660 and at higher education level is 86,034,287 (Nugroho, 2020 cited in Abidah, et al., 2020). To contain the situation, governments apply self-quarantine and physical distancing, thus deliberately increasing the physical space between people to avoid the spread of the virus. As suggested, staying at least six feet apart from others lessens the chances of getting covid-19. Besides, those exposed to the virus or come into contact with the virus were supposed to observe self-quarantine for at least 14 days by which time one would have been diagnosed whether or not they are ill and/or can infect others (Xiao, et al., 2020; Maragakis, 2020). The general public, for that matter students self-quarantined cannot receive visitors and need to stay at quarantine centers, washing hands frequently and practicing standard hygiene. According to Maragakis, (2020) those quarantined are required not to share things like towels and utensils as well stay at least six feet away from other inmates when the need arises.

This paper shared opinion and analysed responses pertaining to the experiences and coping strategies adopted by students of the ongoing self-quarantine during the Movement Control 
Order MCO. The quarantined students are expected to comply for their safety and are provided with the basic necessities. Therefore, this does not include those asked to stay indoors for 14 days due to contact with the infected individuals. The study may be useful to government's policy to actively monitor and design holistic programmes to enhance the emotional and psychological needs of students in future.

The study is designed to:

- $\quad$ examines the stress and coping strategies of students observing self-quarantine and physical distancing.

\section{Method}

This study models a position paper which persuades the reader to realize that the opinions expressed are valid and defensible. Abdul Razzak, (2020) described such a study as conceptual analyses in methodology. Fleming, (2020) identified the following step in writing a position paper as selection of a topic, do preliminary investigation, challenge the topic, search for supporting evidence and define study outline. This study sent out an online interview protocol survey from April 15 to 29, 2020 to examine the stress and coping strategies of students observing selfquarantine in Colleges and around Desa IImu, and Unigardern in Kota Saramarahan Sarawak as well as those in apartments at Jalan Kingfisher Sabah. To support the opinion and argument, online interview protocols were sent to 30 students and subsequently made few calls to verify certain portion of their responses.

\section{Data Collection and Analysis}

the interview protocol was used to enable the researchers to take information from the respondents since protocol is a predetermined sheet on which one logs information learned during the observation or interview (Crouch \& McKenzie, 2006; Neuman \& Neuman, 2006; Tong et al., 2007). The interview protocols were received and reviewed to extract phrases and sentences which were related to the issue under investigation. More than 30 protocols were received and out of which 15 were found suitable to serve as respondent for the study. With an analytical mind, the researchers found transition in meaning perceived as stress symptoms due to quarantine and physical distancing of students. Themes were generated to discover those meanings hidden in the phrases in the various contexts of the investigated phenomenon which are announced in the original protocols. At this point, all the results were organized and gathered into a descriptive form and by doing so the researchers discovered the symptoms of stress and coping strategies employed by students observing self-quarantine at these places. The qualitative data were manually coded and themes generated.

\section{Findings}

Issues with COVID-19 thematically deduced from the discourse of experience of movement control order and ways of coping by students under self-quarantine. Based on the discourses held to look at respondents' experience of the control order, a number of salient themes emerged which were; symptoms of stress, opportunities in frustration, nostalgic feeling, reasonably familiar with isolation, and ways of coping. The subsequent paragraphs deliberately discuss each theme. 


\section{Symptoms of Stress}

In sharing experience of self-quarantine, some respondents indicated of being frustrated due to poor internet connection, limited view, no place to go, plenty of time but less to do and lack of physical contact of people as before. According to Aurra;

besides that, my brain feels weak to focus on what I do and physically weak having problem to do assignments because my brain cannot really function as usual and my body feels weak. In expressing self-quarantine experience, Maina said:

the major ... yes challenge for me is that my Internet connection is very poor during this quarantine which I sometimes will stay up midnight and download everything that I can read during the day time especially for the assignment materials.

They exhibit signs of stress as they have difficulties with nap schedule. Some stay awake deep into the night as sleeping for more than eight hours a day becomes a problem. One respondent claimed that too much sleep for him leads to headache. However, those who were busy or have schedule had different experience from the one expressed above. For instance, Basa shared that: I'm currently staying inside ... college. I'm one of the exco in college and helping ... to control students' movement as well as controlling the data for food aid... (Basa)

The only difficulty for this respondent was how to handle colleague students' movement in the college, other than that quarantine is nice if you know how to handle the stress and leisure. The rules and regulations are for people to stay at home and not do anything or interact with people outside. As per the rules, only a member of the family is allowed to go to buy all the necessities thus applied to those staying at home. But those at quarantine centers, particularly students cannot go to buy on their own personal necessities (food) by themselves but are supplied to them as indicated.

As a result of the disruption of the semester, respondents also express how they are trying hard to rearrange their study plan to include the transportation and accommodation fees when everything is over. As a way of releasing stress, students used to go out to buy supplies but now are not able to go out as they are quarantined making it impossible to travel and socialize as an important human need.

The only reason to go out was to get certain services that were not in the groceries with which the respondents express the difficulty in getting those services. For instance, the concern was the problem of getting a broken laptop fixed at a nearby computer store as it got closed down temporarily due to control order implementation. As a result assignments were being delayed from getting done as one needs to take turns with a friend's laptop. Similarly, other complains were about broken spectacles that could not be fixed because such services were not provided due to the control order so students involved had to manage without their spectacles. There is also report of getting a little bit stressful because of not much things to do apart from scrolling the phone all day. A respondent states that self-quarantine lead to lose of some motivations in doing assignments and final year project FYP since there is more than enough time but less human contact. In expressing the source of stress, Didy said:

it is a stressful experience because I am not able to go out of my ... as much as I do and also, with the extension of the control order, I am not able to start my 2nd half of my 4th semester as scheduled not being able to do a few assignments properly as those assignment requires us to work in a group and do field research ... unable to enjoy decent food not being to socialise with my friends. 
Even though some of them feels more active than before nonetheless express some signs of stress;

... I feel sad at times because I am not able to carry on with my studies because there are not updates on slides and I cannot consult my lecturers especially ... yes my FYP (Eina).

Other than these, some experienced self-quarantine with mix feeling as shown:

it is kind a scary in my opinion it also makes me feel paranoid with my surroundings like whenever people cough or sneeze, it makes you discriminate those who are sick. (Kyalan)

Despite the sense of responsibility to help lessen the number of affected patients, some still feel empty and a bit stressed out living with limited movements and also having the same schedule all day long for almost more than a month. The control order has caused the difficulty in getting some necessities. The respondents attest to the fact of how dangerous it is to go out and how they are overwhelmed with the paranoia of being infected with the virus as well as the boredom of staying at one place.

\section{Nostalgic Feeling}

Where there is attachment, it is natural for one to get bored sometimes especially when individual misses the loved ones and friends so much. Most of the respondents developed nostalgic feelings and yeaned to seeing their parents especially those from Peninsular Malaysia. The burden of the self-quarantine seems minimal as respondents could make video call to have a conversation with friends and family, nevertheless they still prefer face-to-face interaction. This period appeared to be the longest time some have ever stayed away from their parent so it is new experience all together. None of the ever imagined this could happen now as the thought of staying away for long time would have been after graduation and getting job elsewhere. In expressing nostalgic feeling, Loaha said:

my experience is ... for the first time I was as for me, I don't have any difficulties it just I can't go back to Peninsular Malaysia to be with my parents due to the RMO by the ...

One respondent has some of the family members as front liners in the fight of the virus which made her worried about them. She expressed her frustration;

... my aunt and uncle who are the front liners, it makes me feel bad to see how hard they are working while some are still stubborn for not stay at home. (Jintewame)

The respondents are much informed about the virus and how to conduct themselves in observing self-quarantine. The knowledge of the infectious nature of the virus and mode of spread, they said is primarily through droplets of saliva or discharge from the nose when an infected person coughs or sneezes. It is common knowledge for them that to prevent and slow down transmission is by washing of hands or using an alcohol based sanitizer frequently and not touching the face. Another respondent, Maina also has the same difficulties of not being able to go back to see the family back home.

The experience of being stuck in college during the control order and the fact that most of the students had already gone back home was a regrettable thought. The thought of those who left earlier made some of them regret for not leaving the campus same time as their colleagues.

Staying alone without my family during this season frightens me as it concerns our health .... It is hard for me to go out and buy needed resources for me to live in as ... had discouraged students from going out of campus during the .... (Oyadrab) 
The respondents expressed the difficulty not only in getting their parcels but also thoughts of going back to their villages and towns as issues that lingers in their minds during the selfquarantine. Even though there is much time to enjoy, they still feel that the control order should not continue as that will cut them off from home and will lead to boredom and stress. For instance, a respondent explained that:

I cannot enter ... I cannot go out to buy groceries. I cannot proceed my fieldwork as well due to this pandemic ... yes I cannot see Doctor (Nnovital)

Some of them expressed worry not because of being quarantined but the concern is about family members who are also front liners in the fight of the virus. The thought is that the pandemic has created fear among the members of these families considering the stories of getting infected. Nnovital said some of the family members are working in the hospital.

\section{Opportunities in Frustration}

Despite the mix feeling of students like being afraid, anxious, worried or depressed considering the media coverage of alerts in relation to deaths and spread of the disease. Some respondents shared that the self-quarantine was actually helpful as they were able to set new target and able to find pace to boost themselves in academic and club activities. Cisya said he was okay because: My family is thankfully could cope with the pandemic, financial and health wise, my parents still could work and got paid accordingly.

Another respondent shared that;

generally, this pandemic made, me at least, gain a lot of useful information such as the correct way to practice my hygiene, useful tips on how to easily bake or even to reflect myself on my performance in achieving my goals for 2020 (Didy).

As the students stayed indoors without going out for quite some time or do any activities or sports has given them more time than they needed. Jintewame revealed that:

... I got many free times I develop new habit I attend to Google and read some stuff regarding ... including this pandemic that happened around the word.

Loaha also shared with the researchers that:

for the time being, I am fine being self-quarantines as I still got an assignment and task that I need to do yes

Even though the thought of how to find extra money for house rent occupied the mind, there is ample time to learn new things. The self-quarantine allow more time to learn and understand themselves by reflecting on their past actions. Apart from the ample time to study, they also workout new things and learn new knowledge for example cooking.

I tried a lot of new things. This is in terms of decorating, trying do-it-yourself hacks and trying need cooking recipes. Basically, I just unlock my skills during this pandemic. Quite calm and I can predict that this pandemic is going to take a lot of time due to people who doesn't want to stay put inside their house. (Maina)

\section{Reasonably Familiar with Isolation}

The ability to be aware and experience the present has to do with respondent past experience of personal life style thus staying alone without much interaction. The coronavirus COVID-19 disease and student's experience of symptoms of stress like frustration, anxiety and depression as well as fear of its consequences were seen by some to be a normal thing for them. Some of 
the respondents indicated that they did not experience much inconveniences because that is normal life style for them. In expressing how normal the whole situation look like, Aurra said: ... as for me, I feel good and I feel like i can recover from world's exposure and doing some association works really made me to find the interest that l've hiden for some time.

Basa also said;

I don't really have much problems in isolating myself at ... because that's a normal thing for an introvert but one of it would be, not being able to focus on doing my work at ... because I do my assignments well in "academic" surrounding like university area or at libraries

The respondent seems to be normal because he is someone who loves to sit at home alone once in a while rather than socialising outside, he said. Even though Didy is far from home, but still glad because the control order helped them to live together even though observing social distancing, this used to be a hard thing due to individual's busy schedules. Another respondent Eina also said that the quarantine does not affect her much as other people because she is used to staying at home alone.

In compliance with the control order, students' movement was restricted to places of quarantine thus by staying away from others. Students were not allowed go out of the university's territory but all their needs were provided. Firinasa shared that;

... I am currently staying ... the campus, implementing the self-quarantine by staying at ... and observe hygiene standards (washing hands frequently, cough on the tissue or elbow; wear a mask when ...

On the average, respondents indicated that they were feeling fine with self-quarantine because it was for their safety and that of the public and family and therefore decided to remain positive during that period.

overall, it is a thrilling experience as we never know if we are infected or not until the symptoms are out. The only difficulty is to get my basic needs as students in university premise are forbidden to go out. College mart and coop do provide our essential needs but things like face wash and delivery services are hard to get (Disya).

Nnovital said:

I feel a lot better as I get to spend some times ... myself I am able to chill and relax not stressing over works and assignments however, if the order is to be extended, I will be bored and stressed.

\section{Ways of Coping}

It is obvious that if one has a lot of time but less engaged or has less work to do can feel physically and mentally weak and cannot function properly thus become tired as well. Besides, physical distancing does not allow people to mingle with others so less people to have direct contact also spare some time. For them to maintain their composure under self-quarantine, the majority of respondents said they were engaged in either watching movies, drama or attending to academic exercise to keep themselves busy. One respondent said:

since that I'm stuck at college and less people to directly contact with, I'm spending my day by watching movies and dramas, reads news, do some cleaning to ensure my body does exercise even a bit, (Eina)

It appeared to be difficult for those who were very active before the outbreak and the subsequent quarantine as they exhibit signs of frustration for doing nothing. As there is less to do, they found it difficult to concentrate on assignments or think properly. For respondent to sought solace, they 
made friends with WhatsApp as their main source of communication with their parents through phone calls just to remain active and feel less challenged. Aurra indicated that;

assignment is one of the helpful tool to cope with quarantine ... would be readings and others it has been a good time and quality one as I can do stuff that I always wanted to do.

Similarly, another one shared that:

I would reach out to my parents as daily as I could and talk to them about my day. In addition, I would feed and play with cats around by finding other ways to distract me like focusing on assignments or continuing my hobby ... (Basa)

Apart from searching for assignment materials, respondents were also engaged in reading any material they can lay hands on but were smart to avoid sensational news about the virus. In following the rules and regulations by staying at one place, respondents said they spent time watching news about the Covid-19 but focus on the positive information like number of recoveries in the country. According to one respondent:

I always think positive and do some activities inside the house to avoid any stress during the selfquarantine (Oyadrab)

Kyalan also told the researcher that:

in order to survive the order, one needs to look at the bright side of this pandemic and not to panic about the situation one should also look out for each other because everyone is struggling.

The social media also play important role in the life the respondents as most of them said they were engaged in video game, watching movies on Youtube, life-chat or online competitions. Disya shared that:

I rest and do chill activities such as watching movies, cooking, doing assignments also participating in competition organised during this ...

To put it in a simple way, Loaha said;

with peace and not panic I try to occupy myself with studying, movies, music, etc by accepting of the situation.

Ganarn shared that:

I usually get in touch with my families and friends by chatting and video calling them when I start to get bored, I accessed my social media accounts like Instagram and Youtube and Netflix for some entertainments.

Getting on active also depends on how innovative and industrious one can be. To occupy the time, some of the respondents decided to design personal daily schedule and knowing what to at each particular period which keep them busy. With this in place, respondent indicated that the personal schedule made her very organised.

... with a daily basis schedule that I could rely on in order for me to feel more organized and feel the need to tick off some chores from the list such as I include study time, workout time, reading time, etc. (Firinasa)

In similar vain, Maina said that:

... I made myself a study plan where I will make a note or reading at least once a day ... if I am too bored with reading, I will just watch some videos from youtube that will give me a better explanation.

Under situation of this nature it is normal to experience mix feeling as such some of the respondents reported that there were days they felt fine and days that they fell sick of staying at home, but were able to handle the situation. 
INTERNATIONAL JOURNAL OF ACADEMIC RESEARCH IN BUSINESS AND SOCIAL SCIENCES

Vol. 10, No. 5, May, 2020, E-ISSN: 2222-6990 @ 2020 HRMARS

I spend my times doing ... some chores ... watch online movies I also spend my times reading materials that helps to contribute to my knowledge I respond positively as it is for my health and safety ... everything has its bright side (Pasaraza)

\section{Discussion}

This paper focuses on symptoms of stress of students observing self-quarantine under the control order during the COVID-19 pandemic. As the disease continued to spread, the policies to close schools, cities and entire states as well as physical distancing and quarantining were quickly implemented. The rapid spread of the disease, its strong contagion and no specific medicine poses a huge threat to human life and also has a huge impact on the mental health of the general public leading to emotional problems and stress (Gao et al., 2020; Huang, et al., 2020; Polizzi, et al., 2020). The experience expressed by students widely depends on their emotional state and stressors encountered during the period of the self-quarantine. They are reported to have faced fear and uncertainty about the future and how to continue with their studies all of which are symptoms of stress. As rightly put, fear is said to be a good thing as it sometimes leads people to change their behavior if they feel capable of dealing with the threat (viru), but leads to defensive reactions when they feel helpless to act (Van Bavel et al., 2020). The individuals for that matter students, used to complain of lack of time for assignment, many activities competing for less time, lectures, food, weather, uncooperative group members among others in the abundance of everything. The lockdown and control order made students to appreciate lot of things in life that were taken for granted. They realised the importance of small things like how nice it is to talk to colleague students, availability of different eateries with assorted vegetables and food to choose from, health and safety. It may be true that most of them never had these thoughts (selfquarantine) some few months back as some indicated they never expected to be away from the family for that long. Recent studies have shown that the implementation of public health policies such as quarantine of citizens for significant periods of time significantly alter everyday life with both short- and long-term consequences for psychological distress and wellbeing (Brooks et al., 2020; Felix et al., 2020; Polizzi, et al., 2020). As the study revealed, the present situation shakes them but showed them that everything is dependent on something bigger than human can imagined and therefore need to be thankful for all the blessings. With the control order, students also started to appreciate the luxury in interaction, abundance of variety of food products, freedom, health, and the good past moments with colleagues that were appreciated. The best choice among the alternatives as reported is to be grateful otherwise individual might be in a stressful situation. The pandemic brings a lot of issues with profound effects on everyone including students.

At the moment, schools and universities across the globe continue to stay closed leading to the quarantining of students caught up on campuses to keep them safe and to curb the spread of the virus. The public and for that matter students have come to terms with the virus and the fact that without these measures, it will stay for many days or months ahead. Nussbaumer-Streit, Mayr, Dobrescu, Chapman, Persad, Klerings, ... \& Gartlehner, (2020) revealed that combined quarantine with other prevention and control measures like school closures, travel restrictions and social distancing has a larger effect on the reduction of new cases, transmissions and deaths. The control order was necessary for countries to study the virus, understand its dynamics and to allow enough time to educate the public as well as put measure like quarantine to keep people 
safe. Ideally, one need to take a lesson before a test but the reality during the pandemic is that individual gets the test before the lesson. For this reason, authorities do not take chances but implement policies and measures including physical distancing and quarantine. Tang, et al. (2020) explained that the effectiveness of quarantine and isolation determine the trend of the COVID19 epidemics in the final phase. According to Van Bavel et al. (2020), fear that makes threat imminent is an emotional response during pandemic thus negative emotions as result of threat of the virus can be contagious. The government and health authorities keep the public in control order make it necessary for people to live with caution and responsibly. As part of the control order, social distancing measures like cancellation of large events, school closures and reduction of close contact among people through behavioural change as well as self-isolation were measures to reduce transmissions (Preiser, Van Zyl, \& Dramowski, 2020). The COVID-19 pandemic has resulted in a complete change in context considering the many things that students cannot suddenly do in the same way that they used to do and therefore easy to become overwhelmed. In this light, Mandal, et al., (2020) stated that in the absence of a licensed vaccine for COVID-19, quarantine becomes an important strategic containment and mitigation intervention to break the chain of transmission and slow down the spread of the outbreak.

Most world leaders and authorities described the threat of this pandemic as war, a situation where the general public is expected to stay at home for as long as the virus persists. The fear is that the virus is seen as a war fought by army without mercy, guns and bullets, human soldiers, borders or cease-fire agreements. The way forwards as indicated by Preiser et al. (2020) is social distancing measures that prohibit large gatherings, encourages cancellation of large events, school closures, and reduction of close contact between people through attitudinal change. They stated that when implemented simultaneously with self-quarantine, self-isolation of anybody with cough and fever can serve as measures that may likely reduce transmissions. Relatively, the virus taught man that the freedom enjoyed sometimes has a limit as the public including students willingly give up their freedom during self-quarantine in exchange for survival. The lesson learnt and expressed was the nature of the pandemic and how it demands less complains of hunger, argument about conducting classes or studies but to be thankful for seeing another day. The study reveals that most of the respondents did not find the control order stressful but only felt lonely which is very dangerous and a symptom of stress. It is revealed that loneliness and social isolation worsen the burden of stress, and often produce deleterious effects on mental, cardiovascular and immune health (Haslam, et al. 2018; Hawkley, \& Cacioppo, 2010; Van Bavel et al., 2020; Darwish, Ahmed, \& Pahi, 2020). What left most of them thinking include the fear that the virus kills indiscriminately and has no respect for children, women, or places of worship, has no interest in positions nor spoilt after it kills, regime change, rich mineral resources, in religious benefits, ethnic or racial superiority. In order to reduce this fear of getting infected and its spread, governments around the world have issued unprecedented public policies including social distancing, isolation, and self-quarantine (Anderson, et al., 2020; Pakpour, \& Griffiths, 2020). The virus has bases in almost every country of the world without any protocol but a law unto itself. It can only be weakened and defeated through collective action, discipline and cooperation of the general public observing social and physical distancing as well good personal hygiene and keeping the hands sanitized as often as possible. Rogers' (1983) protection motivation theory (PMT) (cited in Pakpour, \& Griffiths, 2020) assumes that individuals engage in health behaviors when their perceived susceptibility and severity are high and perceived rewards 
of maladaptive behaviors are relatively low. The respondent sound optimistic that obeying the instructions of the authorities and exercising patience shall bring back their freedom and social interaction so much yeaned for.

\section{Conclusion}

This study looked at the experiences of the students under self-quarantine as shared. Selfquarantine may help to stop permanently the spread of the virus to other people and offer the front liners the chance to give full attention to those in need. Therefore, quarantine was crucial for authorities to prevent local transmission of the virus and to reduce infection in communities. The study revealed the meaningful and important contribution of self-quarantine not only to the lives of the respondents but also in reducing the number of people that would have been infected and the possible number of deaths. The observation made by some was that the coverage about the pandemic on most television, radio, print and social media focused on the number of infected persons and deaths in big numbers. These rather created frightening circumstances that produced profound psychological effects on all individuals especially those under selfquarantine. There is however the misapplication of the phrase 'social distancing' in place of physical distancing. Social distancing is the level of acceptance people have for social out-group or class. This level of acceptance is the amount of social interaction with people outside their social norm. Social distance is therefore a measure of perceived difference among groups. In this case, race, ethnicity, age, gender, economic class and not wanting to live or work with members of other groups are some of the features of social distancing. In the case of movement control order, physical distancing instead of social distancing may be appropriate since it is referring to a way to prevent the spread of the novel conronavirus from people to people. As cited in Wikipedia, physical distancing is a set of non-pharmaceutical interventions to prevent the spread of a contagious disease by maintaining a physical distance between people and reducing people coming into close contact with one another. Further study could be conducted on the role of social cohesion in addressing the COVID-19 pandemic.

\section{References}

Abdul Razzak, N. (2020). Paulo Freire"s critical and dialogic pedagogy and its implications for the Bahraini educational context. Educational Philosophy and Theory, (Article in press). https://doi.org/10.1080/00131857.2020.1716731.

Abidah, A., Hidaayatullaah, H. N., Simamora, R. M., Fehabutar, D., \& Mutakinati, L. (2020). The Impact of Covid-19 to Indonesian Education and Its Relation to the Philosophy of "Merdeka Belajar". Studies in Philosophy of Science and Education, 1(1), 38-49.

Brooks, S. K., Webster, R. K., Smith, L. E., Woodland, L., Wessely, S., Greenberg, N., Rubin, G. J. (2020). The psychological impact of quarantine and how to reduce it: rapid review of the evidence. Lancet, 395(10227), 912-920.

Crouch, M., \& McKenzie, H. (2006). The logic of small samples in interview-based qualitative research. Social Science Information, 45(4), 483-499.

Darwish, S., Ahmed, U., \& Pahi, M. H. (2020). Innovative Work Behavior During COVID-19 for Medical Representative in the Pharmaceutical Industry: Test of a Moderation Model in Bahrain. International Journal of Pharmaceutical Research. 12(4), 19271934. doi.org/10.31838/ijpr/2020.12.04.277. 
Darwish, S., Ahmed, U., \& Pahi, M. H. (2020). Innovative Work Behavior During COVID-19 for Medical Representative in the Pharmaceutical Industry: Test of a Moderation Model in Bahrain. International Journal of Pharmaceutical Research. 12(4), 19271934. doi.org/10.31838/ijpr/2020.12.04.277.

Emanuel, E. J., Persad, G., Upshur, R., Thome, B., Parker, M., Glickman, A., Zhang, C., Boyle, C., Smith, M., Phillips, J. P. (2020). Fair Allocation of Scarce Medical Resources in the Time of COVID-19. New England Journal of Medicine. https://doi.org/10.1056/NEJMsb2005114

Felix, I. A. M., Ilanit Hasson-O., and Giancarlo, D. (2020). Psychological intervention and COVID19: what we know so far and what we can do DOI: 10.31234/osf.io/8svfa

Hawkley, L. C., \& Cacioppo, J. T. (2010). Loneliness matters: a theoretical and empirical review of consequences and mechanisms. Ann. Behav. Med. Publ. Soc. Behav. Med. 40, 218-227.

Huang, L., Xu, F., \& Liu, H. (2020). Emotional responses and coping strategies of nurses and nursing college students during COVID-19 outbreak. medRxiv.

Mandal, S., Bhatnagar, T., Arinaminpathy, N., Agarwal, A., Chowdhury, A., Murhekar, M., ... \& Sarkar, S. (2020). Prudent public health intervention strategies to control the coronavirus disease 2019 transmission in India: A mathematical model-based approach. Indian J Med Res, 151.

Maragakis, L. L. (2020). Coronavirus, social distancing and self-quarantine. Retrieved from https://www.hopkinsmedicine.org/health/conditionsanddiseases/coronavirus/coronavirus-social-distancing-and-self-quarantine

Neuman, W. L., \& Neuman, W. L. (2006). Social research methods: Qualitative and quantitative approaches. University of Wisconsin U.S A. MA: Allyn and Bacon Publisher

Nicomedes, C. J., \& Avila, R. (2020). An Analysis on the Panic of Filipinos During COVID-19 Pandemic in the Philippines.

Nugroho, R. S. (2020, March 14). Corona: 421 juta pelajar di 39 negara belajar di rumah, kampus di Indonesia Kuliah Online. Retrieved March 28, 2020, https://www.kompas.com/tren/read/2020/03/14/120000765/corona-421-jutapelajardi-39-negara-belajar-di-rumah-kampus-di-indonesia.

Pakpour, A. H., \& Griffiths, M. D. (2020). The fear of CoVId-19 and its role in preventive behaviors. Journal of Concurrent Disorders.

Polizzi, C., Lynn, S. J., \& Perry, A. (2020). Stress and Coping in the Time of COVID-19: Pathways to Resilience and Recovery. Clinical Neuropsychiatry, 17(2), 59-62.

Preiser, W., Van Zyl, G., \& Dramowski, A. (2020). COVID-19: Getting ahead of the epidemic curve by early implementation of social distancing. SAMJ: South African Medical Journal, 110(4), 0-0.

Shanthakumar, S. G., Seetharam, A., \& Ramesh, A. (2020). Understanding the Socio-Economic Disruption in the United States during COVID-19's Early Days. In Proceedings of ACM Conference (Conference'17). ACM, NewYork,NY, USA, 5 pages. https://doi.org/10.1145/nnnnnnn.nnnnnnn

Tang, B., Xia, F., Tang, S., Bragazzi, N. L., Li, Q., Sun, X., ... \& Wu, J. (2020). The effectiveness of quarantine and isolation determine the trend of the COVID-19 epidemics in the final phase of the current outbreak in China. International Journal of Infectious Diseases. 
Tong, A., Sainsbury, P., \& Craig, J. (2007). Consolidated criteria for reporting qualitative research (COREQ): a 32-item checklist for interviews and focus groups. International Journal for Quality in Health Care, 19(6), 349-357.

UNESCO. (2020). Education emergencies. Retrieved April 8, 2020 from https://en.unesco.org/themes/education-emergencies/coronavirus-school-closures.

Wang, C., Pan, R., Wan, X., Tan, Y., Xu, L., Ho, C. S., y Ho, R. C. (2020). Immediate Psychological Responses and Associated Factors during the Initial Stage of the 2019 Coronavirus Disease (COVID-19) Epidemic among the General Population in China. International Journal of Environmental Research and Public Health, 17(5). https://doi.org/10.3390/ijerph17051729

World Health Organization (WHO). (2020). Coronavirus disease (COVID-19) technical guidance: Infection prevention and control / WASH. Retrieved on April 2, 2020 from https://www.who.int/emergencies/diseases/novel-coronavirus-2019/technicalguidance/infection-prevention-and-control

Xiao, C. (2020). A Novel Approach of Consultation on 2019 Novel Coronavirus (COVID-19)-Related Psychological and Mental Problems: Structured Letter Therapy. Psychiatry Investigation, 17(2), 175-176.

Xiao, H., Zhang, Y., Kong, D., Li, S., \& Yang, N. (2020). Social Capital and Sleep Quality in Individuals Who Self-Isolated for 14 Days During the Coronavirus Disease 2019 (COVID-19) Outbreak in January 2020 in China. Medical science monitor: international medical journal of experimental and clinical research, 26, e923921-1.

Zhou, X. (2020). Psychological crisis interventions in Sichuan Province during the 2019 novel coronavirus outbreak. Psychiatry Research, 286(February), 112895.

https://doi.org/10.1016/j.psychres.2020.112895 